\title{
TERRITORIAL DIFFERENTIATION IN EU LAW: CAN SCOTLAND AND NORTHERN IRELAND REMAIN IN THE EU AND/OR THE SINGLE MARKET?
}

\author{
Nikos Skoutaris
}

\begin{abstract}
In the Brexit referendum of 23 June 2016, voters in England and Wales voted to leave the EU, while in Scotland and Northern Ireland voted to remain. Following that, there has been a debate about how it would be possible to achieve the continuing presence in the single market of the UK constituent nations that do not want to be taken out against their will. This paper explores two pathways for Scotland and Northern Ireland to remain in the EU and/or the single market. The first entails the achievement of Scottish independence and the reunification of Ireland through democratic referendums. To this effect, the paper reviews the right of secession of those two constituent nations under UK constitutional law. It revisits the debate on the appropriate legal basis regulating Scotland's future EU Accession and discusses the Irish reunification from an EU law perspective. The second pathway explores how it would be possible for Scotland and Northern Ireland to remain in the EU and/or the single market even without seceding from the UK. In order to do that, the paper points to the remarkable flexibility of the EU legal order as evidenced in numerous cases of differentiated application of Union law. The paper shows that the EU possesses the necessary legal instruments to accommodate the divergent aspirations of the UK constituent nations.
\end{abstract}

\section{Keywords}

Brexit; Differentiated Brexit; Secession; Reunification; Territorial differentiation.

\footnotetext{
- Lecturer in EU law, University of East Anglia. I would like to thank professors M Cremona, C Kilpatrick, KA Armstrong and the anonymous reviewers for their comments in earlier drafts and Dr C Ní Ghiollarnáth for language editing. Special thanks to Ion Skoutaris Gonzalez for his encouragement. The usual disclaimers apply. An earlier version of this paper was published by the Academy of European Law (EUI) as part of its Working Papers series under the title 'From Britain and Ireland to Cyprus: Accommodating 'Divided Islands' in the EU Political and Legal Order'.
} 


\section{INTRODUCTION}

On 23 June 2016, 52 per cent of voters that participated in the Brexit referendum voted to leave the EU. Still, Scotland and Northern Ireland, two out of the four UK constituent nations, voted to remain. ${ }^{1}$ As a result, the following morning, the First Minister of Scotland, Nicola Sturgeon, made clear that she intended to 'take all possible steps and explore all options to give effect to how people in Scotland voted in other words, to secure [their] continuing place in the EU and in the single market in particular.' 2 The reason being that 'Scotland faces the prospect of being taken out of the EU against [its] will. ${ }^{3}$ At the same time, Sinn Féin called for a referendum for the unification of Ireland and thus for Northern Ireland to remain in the EU. ${ }^{4}$ It was even reported at the time that Gibraltar was in talks with Scotland in order to remain in the EU. ${ }^{5}$

Some months later, the Scottish Government released its blueprint on how Scotland could remain in the single market post-Brexit by participating in the European Economic Area. ${ }^{6}$ On behalf of the UK Government, David Davis rejected those proposals. ${ }^{7}$ Whitehall also rejected the Scottish demand for a second independence referendum that could potentially lead to EU membership. ${ }^{8}$ Such demand became official when the Scottish Parliament passed a motion to give Nicola Sturgeon the authority to begin negotiations with Westminster on a breakaway vote. ${ }^{9}$ The UK government signalled that it would not consent to a second independence referendum before the Brexit negotiations have ended. ${ }^{10}$ Following the general elections of June 2017, the Scottish First Minister conceded 'that the Scottish Government would not [...] seek to introduce the legislation for an independence referendum immediately, but would rather return to the issue at the end of the negotiations. ${ }^{11}$

The collapse of the power-sharing arrangement in Northern Ireland, on the other hand, has meant that the Northern Ireland Executive has been less active than the Scottish Government in presenting the views of the region. The two biggest political parties representing the two ethno-religious segments have expressed

\footnotetext{
${ }^{1}$ In Scotland, 62 per cent voted to remain in the EU, while 56 per cent in Northern Ireland. In England, 53 per cent voted to leave while 52.5 per cent in Wales.

${ }^{2} \mathrm{~N}$ Sturgeon's speech after the referendum result, available at stv.tv/news/politics/1358534-nicolasturgeon-speech-in-full-after-eu-referendum-result/ (last visited 28 August 2017).

${ }^{3}$ Ibid.

${ }^{4}$ See www.businesspost.ie/sinn-fein-seeks-irish-reunification-vote-as-britain-votes-for-brexit/ (last visited 28 August 2017).

${ }^{5}$ See http://www.bbc.co.uk/news/uk-politics-eu-referendum-36639770 (last visited 28 August 2017).

${ }^{6}$ See Scottish Government, Scotland's Place in Europe available at http://www.gov.scot/Publications/2016/12/9234 (last visited 28 August 2017).

${ }^{7}$ See http://www.parliament.scot/S5_European/General\%20Documents/CTEER_Minister_M.Russell_ 2017.04.27.pdf (last visited 28 August 2017).

${ }^{8}$ See https://www.theguardian.com/politics/2017/mar/16/theresa-may-rejects-nicola-sturgeons-scottishreferendum-demand (last visited 28 August 2017).

${ }^{9}$ See http://www.independent.co.uk/news/uk/politics/nicola-sturgeon-indyref2-uk-government-formalrequest-second-scottish-independence-referendum-a7659996.html (last visited 28 August 2017).

10 See https://www.theguardian.com/politics/scottish-independence-blog/live/2017/mar/28/scottishparliament-debate-independence-refeerendum-indyref2-sturgeon-mayor-urges-eu-citizens-to-press-forbrexit-deal-that-does-not-punish-uk-politics-live?page=with:block58da9019e4b007e8557f072c\#block-58da9019e4b007e8557f072c (last visited 28 August 2017).

11 See House of Lords, European Union Committee, Brexit: Devolution available at https://publications.parliament.uk/pa/ld201719/ldselect/ldeucom/9/9.pdf (last visited 28 August 2017), para 6.
} 
opposite views with regard to Brexit. The Democratic Unionist Party (DUP hereafter) supported Leave while Sinn Féin campaigned for Remain. Notwithstanding, in their post-referendum letter to the Prime Minister, the then First Minister and the Deputy First Minister highlighted the need to ensure that the Irish border does not become an impediment to the movement of goods, services and capital. ${ }^{12}$ In her letter to Donald Tusk with which she triggered Article 50 TEU, the UK Prime Minister Theresa May also expressed her intention 'to avoid a return to a hard border', ${ }^{13}$ a goal that is shared by the EU. ${ }^{14}$ Of course, if Northern Ireland remains part of the single market and the EU customs union after Brexit, the hard border will be avoided. However, such scenario seems less feasible in the aftermath 'of the 2017 general election, and the subsequent agreement between the Conservative Party and the DUP. ${ }^{15}$ The proposal on the Irish border that the UK Government released and for which DUP was consulted ${ }^{16}$ envisages Northern Ireland outside the single market and the EU customs union. $^{17}$

Notwithstanding, the question that this paper wishes to address is how it could be made possible for the two UK constituent nations that voted to remain not to be taken out of the EU and/or the single market against their expressed will, as a significant part of their political elites has been arguing. The paper presents two pathways. The first entails the secession of Scotland and Northern Ireland from the UK through democratic referendums. To this effect, it briefly reviews their right to secession under UK constitutional law. We note that, while the Northern Ireland Act provides for the right of secession of Northern Ireland, ${ }^{18}$ the Scottish situation is more complicated. Assuming that those referendums would take place and Scotland and Northern Ireland would secede from the UK, we explore how they could achieve continuing membership of the EU or just the single market by joining the European Free Trade Association (EFTA) and the European Economic Area (EEA).

The second pathway explores how it would be possible for Scotland and Northern Ireland to remain in the EU and/or the single market even without seceding from the UK. In order to do that, the paper briefly revisits a number of cases where different parts of a Member State may have different relationships with the EU and/or the single market.

The relevant examples of differentiated application of EU law include Greenland, Svalbard, the Faroe Islands and even Cyprus, which is the only Member State where the acquis does not apply to a significant part of its territory ${ }^{19}$ and where there is a territorial border between the part where it applies and where it does not. Of

\footnotetext{
${ }^{12}$ Available at https://www.executiveoffice-ni.gov.uk/sites/default/files/publications/execoffice/Letter\% 20to\%20PM\%20from\%20FM\%20\%26\%20dFM.pdf (last visited 28 August 2017).

${ }^{13}$ Available at http://www.independent.co.uk/news/uk/politics/article-50-letter-read-full-brexit-theresamay-takes-uk-out-of-eu-statement-a7655566.html (last visited 28 August 2017).

${ }^{14}$ See para 14 of the EU Negotiating Directives http://www.consilium.europa.eu/en/press/pressreleases/2017/05/22-brexit-negotiating-directives/ (last visited 28 August 2017).

${ }^{15}$ See above $n 11$, para 7.

16 See http://www.telegraph.co.uk/news/2017/08/16/arlene-foster-says-dup-helped-shape-uksproposals-irish-border/ (last visited 28 August 2017).

17 UK Government Position Paper, Northern Ireland and Ireland available at https://www.gov.uk/government/uploads/system/uploads/attachment_data/file/638135/6.3703_DEXEU Northern_Ireland_and_Ireland_INTERACTIVE.pdf (last visited 28 August 2017).

${ }^{\overline{18}}$ Such right is not unilateral. As we shall see in the following section, Schedule 1 of the Northern Ireland Act 1998 provides that a referendum for the reunification of Ireland can only be organised if "it appears likely to [the UK Secretary of State] that a majority of those voting would express a wish that Northern Ireland should cease to be part of the United Kingdom and form part of a united Ireland.'

${ }^{19}$ Almost 40 percent.
} 
course, all those cases to which we refer are politically, historically and even legally very different from a future arrangement where Scotland and Northern Ireland remain as parts both of the UK and the EU. However, we note the remarkable flexibility of the Union legal order that has allowed for such differentiation. More importantly, those legal arrangements could offer some much needed inspiration if Scotland and Northern Ireland were to decide to remain in the EU and/or the single market without seceding from the UK.

\section{SECEDING FROM THE UK, REMAININING IN THE EU}

The first pathway that could ensure that Scotland and Northern Ireland remain in the $\mathrm{EU}$ and/or the single market entails their secession from the UK through democratic referendums. This would lead to Scottish independence and the reunification of Ireland respectively. According to section 1 of Northern Ireland Act 1998, Northern Ireland enjoys a right to secede to join a United Ireland if the majority of its people agree to this in a referendum. ${ }^{20}$ On the other hand, the Scottish devolution arrangement does not include a similar constitutional provision. In case, the two regions democratically choose to secede from the UK, the next question is how they could join the EU and/or the single market under EU law and the law of the EFTA and the EEA.

\section{A. The Internal Constitutional Question}

\section{Scottish Independence}

The Scottish Parliament has had the power to enact primary legislation from the very beginning. Its powers are defined negatively. This means that, according to section 29 of Scotland Act 1998, it may legislate in areas that are not considered as 'reserved' competences of Westminster. The latter are enlisted in Schedule 5 of Scotland Act 1998, which provides for a list of those 'reserved matters' over which the Scottish Parliament does not have legislative authority. According to Lord Hope,

'The fact that section 29 provides a mechanism for determining whether a provision of an Act of the Scottish Parliament is outside, rather than inside, competence does not create a presumption in favour of competence. But it helps to show that one of the purposes of the 1998 Act was to enable the Parliament to make such laws within the powers given to it by section 28 as it thought fit. It was intended, within carefully defined limits, to be a generous settlement of legislative authority. ${ }^{21}$

The Scottish Parliament has residual powers over the legislative competences that are not explicitly allocated to Westminster. The latter include the Constitution of which 'the Union of the Kingdoms of Scotland and England' is part. This means that '[a]s a matter of UK law, the Scottish Parliament cannot pass a declaration of independence.' ${ }^{22}$ However, referendums are not listed as a reserved matter in Schedule 5. Therefore, there is a question to be made whether Holyrood can lawfully

\footnotetext{
${ }^{20}$ The people of the Irish Republic should also agree to this in a separate referendum.

${ }^{21}$ Imperial Tobacco Limited v. The Lord Advocate (Scotland) [2012] UKSC 61, para 15.

${ }^{22}$ E Smith and A Young, "That's how it worked in 2014, and how it would have to work again" UK Constitutional Law Blog available at https://ukconstitutionallaw.org/2017/03/15/ewan-smith-andalison-young-thats-how-it-worked-in-2014-and-how-it-would-have-to-work-again/ (last visited 28 August 2017).
} 
'hold a referendum about whether another constitutional institution should do so., 23 To put it differently, it is rather unclear whether the Scottish Parliament can exercise the unreserved power to hold an advisory referendum for a reserved matter such as 'the Union of the Kingdoms of Scotland and England'.

This was precisely the topic of the constitutional debate that took place between academics and political elites in the aftermath of the landslide win of the Scottish National Party in the 2011 Scottish Parliament elections. ${ }^{24}$ Central to that debate was the question whether an Act of the Scottish Parliament allowing the organisation of an independence referendum would relate directly to the reserved matter of the Constitution and thus it would be deemed ultra vires. Notwithstanding the legal arguments, ${ }^{25}$ the 'two governments of Scotland' decided to resolve this important constitutional question with a political agreement. ${ }^{26}$ The Edinburgh Agreement ${ }^{27}$ underscores the flexible nature of the UK idiosyncratic constitution. According to it, David Cameron and Alex Salmond agreed to amend the text of Scotland Act 1998. In accordance with section 30 of the Act, ${ }^{28}$ an $\operatorname{Order}^{29}$ was issued that introduced new section 29A. This new section explicitly conferred the power on Holyrood to organise an independence referendum by no later than 31 December 2014.

More importantly for the purposes of the present article, on 28 March 2017, Holyrood passed a motion according to which there should be another independence referendum. Following that, Nicola Sturgeon asked Theresa May 'to begin early discussions between our governments to agree an Order under section 30 of the Scotland Act 1998 that would enable a referendum to be legislated for by the Scottish Parliament. ${ }^{30}$ By asking Whitehall to allow the organisation of the referendum, the Scottish First Minister has accepted -implicitly- that a convention at a minimum or a legal obligation at a maximum has been created whereby Holyrood needs to seek the permission of the UK Government.

\footnotetext{
${ }^{23}$ Ibid.

${ }^{24}$ For an analysis of the debate, see A McHarg et al. (eds), The Scottish Independence Referendum: Constitutional and Political Implications (Oxford University Press, 2016); KA Armstrong, 'The Reach and Resources of European Law in the Scottish Independence Referendum' in C Closa (ed), Secession from a Member State and Withdrawal from the European Union: Trouble Membership (Cambridge University Press, 2017), 106.

${ }^{25}$ For a view in favour of Holyrood's powers to organise such a referendum see for example N Barber, 'Scottish Independence and the Role of the United Kingdom' UK Constitutional Law Blog available at https://ukconstitutionallaw.org/2012/01/11/nick-barber-scottish-independence-and-the-role-of-theunited-kingdom/ (last visited 28 August 2017). Contra see for example A Tomkins, 'The Scottish Parliament and the Independence Referendum' available at https://ukconstitutionallaw.org/2012/01/12/adam-tomkins-the-scottish-parliament-and-theindependence-referendum/ (last visited 28 August 2017)

${ }^{26}$ For an analysis of the legal nature of the Edinburgh Agreement, see C Bell, 'The Legal Status of the Edinburgh Agreement', available at

www.scottishconstitutionalfutures.org/OpinionandAnalysis/ViewBlogPost/tabid/1767/articleType/ ArticleView/articleId/431/Christine-Bell-The-Legal-Status-of-the-Edinburgh-Agreement.aspx (last visited 28 August 2017).

${ }^{27}$ The text of the Agreement is available at http:/www.number10.gov.uk/wpcontent/uploads/2012/10/Agreement-final-for-signing.pdf (last visited 28 August 2017).

${ }^{28}$ s.30 (2) of the Scotland Act 1998 provides that 'Her Majesty may by Order in Council make any modifications' of the reserved matters 'which She considers necessary or expedient.'

${ }^{29}$ The Scotland Act 1998 (Modification of Schedule 5) Order 2013.

${ }^{30}$ Available at https://www.snp.org/nicola_sturgeon_s_section_30_letter_to_theresa_may (last visited 28 August 2017).
} 
Concerning conventions, one has to highlight that they are politically and not legally binding as the Supreme Court reminded us in Miller. ${ }^{31}$ Notwithstanding, it seems that the constitutional right of the Scottish legislature to organise another independence referendum is at least disputed. This is why the Scottish Government tries to achieve a similar political arrangement to the one that led to the Edinburgh Agreement. Interestingly enough, Mac Amlaigh has argued that the Scottish First Minister may use the potential veto power of Holyrood over Brexit legislation as leverage in order for Westminster to allow such a referendum to take place. ${ }^{32}$ To this effect, it is important to note that the First Ministers of Scotland and Wales have already warned that their Governments 'cannot recommend that legislative consent is given to the [EU (Withdrawal)] Bill as it currently stands. ${ }^{33}$ In fact, in a recent meeting, Nicola Sturgeon and Carwyn Jones reaffirmed their view that the EU Withdrawal Bill 'must not be allowed to progress in its current form' and asked 'the UK Government to respond positively to [their] suggested amendments. ${ }^{34}$

\section{Irish Reunification}

Unlike the case of Scotland, 'Westminster has formally conceded that Northern Ireland can secede from the United Kingdom to join a united Ireland, if its people, and the people of the Irish Republic, voting separately, agree to this. ${ }^{35}$ Section 1 of the Northern Ireland Act 1998 is a rare example of a provision of a constitutional statute explicitly recognising the right of secession of a region. ${ }^{36}$ In that sense, the organisation of such a referendum faces less constitutional hurdles - at least from a UK constitutional law point of view. ${ }^{37}$ This does not mean that it is politically more

\footnotetext{
${ }^{31} R$ (on the application of Miller and another) $v$ Secretary of State for Exiting the European Union [2017] UKSC 5, para 146.

${ }^{32} \mathrm{C}$ Mac Amhlaigh, 'Scotland Can Veto Brexit (sort of...)', available at
}

http://verfassungsblog.de/scotland-can-veto-brexit-sort-of/ (last visited 28 August 2017). According to this argument, Westminster would not normally legislate in areas devolved to Scotland without the consent of the Scottish Parliament. This is known as the 'Sewell Convention. Since its inception, the scope of the convention has evolved so as to require the consent of the Scottish Parliament, not only where the UK Parliament seeks to legislate in devolved policy areas, but beyond that where a UK bill seeks to vary the legislative competence of the Scottish Parliament or the executive competence of the Scottish Ministers. So, given the way the European Communities Act 1972 (ECA) and EU law in general are embedded in the Scotland Act (see eg section 29 of the Scotland Act 1998), 'a repeal of the ECA to give legal effect to Brexit would trigger the Sewell Convention'.

${ }^{33}$ Available at https://news.gov.scot/news/eu-withdrawal-bill (last visited 28 August 2017).

${ }^{34}$ Available at

http://www.heraldscotland.com/news/15489005.Constitutional_crisis_looms_as_Sturgeon_and_Jones join_forces_to_oppose_Westminster_post_Brexit_quot_power_grab_quot_/?ref $=$ ebln (last visited 28 August 2017).

${ }^{35}$ J McGarry, 'Asymmetrical Autonomy in the United Kingdom' in Marc Weller and Katherine Nobbs (eds), Asymmetric Autonomy and the Settlement of Ethnic Conflicts (University of Pennsylvania Press 2010) 148, 156.

${ }^{36}$ Other examples of constitutional provisions that provide for a right of secession include Article 39(1) of the Ethiopian Constitution according to which 'every nation, nationality or people in Ethiopia shall have the unrestricted right to self determination up to secession' and; Article 4(2) of the Constitution of the Principality of Liechtenstein according to which '[i]ndividual municipalities shall be entitled to secede from the union. The decision on whether to initiate a secession procedure shall be made by a majority of the Liechtenstein citizens eligible to vote who reside there. Secession shall be regulated by a law or, as the case may be, by an international treaty. If secession is regulated by a treaty, a second vote shall be held in the municipality after the treaty negotiations have been concluded.'

${ }^{37}$ If one looks at the Irish Constitution, and especially at the text of the revised Articles 2 and 3, s/he would realise that there is nothing that explicitly states that the Taoiseach is obliged by the Constitution, and the duties of his office, to pursue a United Ireland. 
feasible. In fact, according to Schedule 1 of the Northern Ireland Act, a referendum for the reunification of Ireland can only be organised if 'it appears likely to [the UK Secretary of State] that a majority of those voting would express a wish that Northern Ireland should cease to be part of the United Kingdom and form part of a united Ireland.' Theresa Villiers, the former Northern Ireland Secretary has made clear that, according to her, "there is nothing to indicate that there is majority support for a poll. ${ }^{38}$ To this effect, one has to bear in mind that there does not seem to be agreement among the Northern Irish political elites concerning the need to organise such a referendum and that the ethno-religious segment that would be more willing to support the reunification of Ireland i.e. the Republican one, is in the minority.

\section{B. The EU law perspective}

\section{Article 48 or Article 49: That is the Question}

Now let us assume, for the purposes of the present paper, that Whitehall and Holyrood reach a similar agreement to the one that led to the 2014 referendum and that the Scottish electorate votes in favour of independence in that second referendum. The next question we should address is what is the appropriate legal basis in order for Scotland to become an EU or an EFTA/EEA Member State.

Starting with EU membership, we note that although Article 49 TEU provides for a clear legal basis for the EU accession of new Member States, the Scottish government and a number of experts suggested in $2014^{39}$ that a different legal basis was applicable. Article 49 TEU provides that '[a]ny European State which respects the values referred to in Article 2 and is committed to promoting them may apply to become a member of the Union'. After receiving such an application, the Council has to unanimously decide on opening the Accession negotiations after consulting with the Commission and receiving the consent of the majority of the component members of the European Parliament. The negotiations are compartmentalised in chapters and are driven by soft law instruments in the form of bilateral accession partnerships and progress reports. ${ }^{40}$ Once there is an agreement that the candidate State has complied with all the relevant conditions contained in all the negotiating chapters, an Accession Treaty is drafted. The Treaty provides for all '[ $t$ ]he conditions of admission and the adjustments to the Treaties on which the Union is founded, which such admission entails. ${ }^{41}$ The signatories are the Union Member States and the candidate State. The Member States have to ratify the Accession Treaty in accordance with their respective constitutional requirements. Innocuous as it may sound, this might prove a cumbersome process given some recent constitutional developments. For instance, the amended Article 88-5 of the French Constitution provides that the ratification of an Accession Treaty could be submitted to referendum unless the Parliament decides differently with an enhanced majority of three fifths.

Clearly, the procedure under Article 49 TEU can be arduous and cumbersome. However, this has not been the only concern that made the Scottish government

\footnotetext{
${ }^{38}$ Available at www.theguardian.com/uk-news/2016/jun/24/arlene-foster-northern-ireland-martinmcguinness-border-poll-wont-happen (last visited 28 August 2017).

${ }^{39}$ For the different views on this debate, see http://verfassungsblog.de/category/focus/scotlands-eumembership/ (last visited 28 August 2017).

${ }^{40}$ For a brief analysis, see C Hillion, 'EU Enlargement' in P Craig and G de Búrca, (eds), The Evolution of EU Law, 2nd ed, (Oxford University Press, 2011), 187; C Hillion, 'Accession and Withdrawal in the Law of the European Union' in A Arnull and D Chalmers (eds), The Oxford Handbook of European Union Law (Oxford University Press 2015) 126.

${ }^{41}$ Art 49(2) TEU.
} 
explore alternative routes to Union membership. It is mainly the fact that, if Scotland follows that procedure, it will find itself outside the EU between the time of its independence and the time of its Accession to the EU. This might be a significant time period during which 'Scotland's laws, policies and regulatory structures could diverge sharply from the EU's'. ${ }^{42}$

In the long hours of the morning of 19 September 2014, the then Spanish Foreign Minister made clear that if Scotland had become independent, it would have had to join the queue of the other candidate States, underlining how time-consuming this might be. More importantly, his statement shed doubt on whether Spain would ever accept Scotland as a Member State, fearing that this would create a dangerous precedent especially for the secessionist movements that exist in Spain.

In any case, the official position of the Commission at the moment was that 'If part of the territory of a Member State would cease to be part of that State because it were to become a new independent state, the Treaties would no longer apply to that territory. In other words, a new independent state would, by the fact of its independence, become a third country with respect to the EU and the Treaties would no longer apply on its territory.' 43

Thus, it would have to follow the procedure under Article 49 TEU in order to become an EU Member State.

However, the Scottish Government had a different view. They based their argument ${ }^{44}$ on the fact that the Scottish situation is sui generis. It would be the first time that a region would secede from an EU Member State by a consensual and lawful constitutional process. It did so in order to differentiate itself from other secessionist claims in Europe and to ease the concerns of the respective metropolitan States. According to the Scottish position, Article 49 only regulates 'conventional enlargement where the candidate country is seeking membership from outside the EU'. ${ }^{45}$ But Scotland is part of the EU since 1973. Therefore, the appropriate legal basis that would facilitate Scotland's transition to Union membership is Article 48 TEU, the generic provision on the amendment of the EU Treaties. In other words, the Scottish position has been that the amendment of Article 52 TEU, which provides for the States to which the Treaties apply and the relevant Articles concerning the composition of the EU institutions would be, by and large, sufficient in order for Scotland to become an EU Member State after its independence.

Of course, it has to be noted that after June's general election, Nicola Sturgeon has suggested that "any "indyref2" would need to wait until a Brexit deal was clear -

\footnotetext{
${ }^{42}$ K Hughes, 'Brexit Transition, Scotland and Independence: Has a New Route Opened Up?', available at https://www.scer.scot/database/ident-3193 (last visited 28 August 2017).

${ }^{43}$ President JM Barroso's letter of 10.12.2012 to the House of Lords Economic Affairs Committee regarding the status of EU membership for Scotland in the event of independence. In fact, this letter follows almost verbatim a similar position expressed by a previous President of the Commission $\mathrm{R}$ Prodi in 2004. According to it, '[w] hen a part of the territory of a member-state ceases to be a part of that state, e.g. because the territory becomes an independent state, the Treaties will no longer apply to that territory. In other words, a newly independent region would, by the fact of its independence, become a third country with respect to the Union and the Treaties would from the day of its independence, not apply anymore...' If the new country wished them again to apply there would need to be ... 'a negotiation on an agreement between the applicant state and the member-states on the conditions of admission and the adjustments to the Treaties which such admission entails. This agreement is subject to ratification by all member-states and the applicant state.' (President R Prodi to the European Parliament Official Journal of the European Union, C84E/422 (3.4.2004)).On

${ }^{44}$ See Scottish Government's blueprint on Scotland's Future 216-224 available at www.gov.scot/resource/0043/00439021.pdf (last visited 28 August 2017).

${ }^{45}$ Ibid, 21.
} 
pushing the likely timetable to after the UK's departure from the EU in March 2019. ${ }^{46}$ This makes the use of Article 48 TEU for securing Scotland's continuing EU membership virtually impossible. Only a transitional arrangement that would entail the remaining of the UK both in the single market and the EU's customs union until the moment Scotland joins the EU as an independent State could potentially bring this legal arrangement back into play. ${ }^{47}$ Interestingly, in a recent article, Labour's Shadow Secretary of State for Exiting the EU, Keir Starmer, announced that the opposition party supports such transitional arrangement. ${ }^{48}$

Be that as it may, I would still argue that, in the current legal framework, Article 49 TEU is the appropriate legal basis to regulate Scotland's EU accession. The reason is the following. 'The choice of the legal basis for a [certain measure and/or action] may not depend simply on an institution's [or Member States'] conviction as to the objective pursued but must be based on objective factors... Those factors include in particular the aim and content of the' action. ${ }^{49}$ So, as long as the objective pursued by this treaty amendment will be the accession of a new Member State, the EU Treaties provide for a lex specialis rule, i.e. Article 49 TEU. In other words, if the Treaty on European Union is interpreted in accordance with the ordinary meaning to be given to its terms, following the well established rule of Article 31(1) of the Vienna Convention on the Law of the Treaties, it would be difficult to justify the use of the generic provision on the amendment of the Treaties (Article 48 TEU) when there is a special provision regulating the accession of new Member States (Article 49 TEU). Of course, the counterargument is that it would not be the accession of a new Member State but rather a change in status of an entity that is already part of the EU. From a public international law perspective, this is a rather unconvincing argument. ${ }^{50}$ If Scotland secedes from the UK, it would be considered to be a newly independent country under public international law. It would have to apply to be admitted as the $194^{\text {th }}$ member of the United Nations. In that sense, it would be a new European State that would also have to apply for EU membership under Article 49 TEU.

It is important to note that the EU Treaties, including Articles 48 and 49 TEU, do not make any distinction based on the process of the formation of the States with regard to their EU accession. If the EU and the Member States opted for Article 48 in order to regulate Scotland's EU Accession, they would de facto distinguish between European States that have become independent from old Member States through a consensual procedure and the rest. Consequently, they would create a special procedure for the EU accession of the former, although this is not envisaged in the Treaties. Of course, the Member States as Masters of the Treaties could always amend the text in order to provide for such a distinction. But until that happens, Article 49 TEU seems like the more appropriate procedure, also because it allows for the same level of pre-accession scrutiny that all the candidate States have to be subjected to.

\footnotetext{
${ }^{46}$ Above $\mathrm{n} 42$.

${ }^{47}$ Ibid.

${ }^{48}$ K Starmer, 'No 'constructive ambiguity". Labour will avoid Brexit cliff edge for UK economy' available at https:/www.theguardian.com/commentisfree/2017/aug/26/keir-starmer-no-constructiveambiguity-brexit-cliff-edge-labour-will-avoid-transitional-deal (last visited 28 August 2017).

${ }^{49}$ Commission v Council, C-300/89, EU:C:1991:244.

${ }^{50}$ Equally unconvincing from a public international law perspective is the suggestion that Scotland could also be seen as representing the continuing UK membership (A O'Neill 'England's Difficulty; Scotland's Opportunity', available at http://verfassungsblog.de/englands-difficulty-scotlandsopportunity/ (last visited 28 August 2017). To this effect, see J Crawford and A Boyle, 'Opinion: Referendum on the Independence of Scotland - International Law Aspects', available at https:/www.gov.uk/government/uploads/system/uploads/attachment_data/file/79408/Annex_A.pdf (last visited 28 August 2017).
} 
The fact that accession negotiations are more often than not lengthy has led a number of Scottish politicians including the former First Minister Alex Salmond to propose "that Scotland would try and join EFTA as a "transition" for an undefined period, before applying to join the EU in the longer term. ${ }^{51}$ Article 56 of the EFTA Convention provides that any State may accede to it on terms and conditions set out in a unanimous decision of the highest governing body: the EFTA Council. Following such decision of the four EFTA States that take part in the Council, ${ }^{52}$ Scotland may apply to join EEA in accordance with Article 128 of the EEA Agreement. All Contracting Parties should approve the Accession Agreement.

The benefit of the 'Norway model' is that it secures the continuous membership to the EU's single market until Scotland becomes an EU Member State. Even as a permanent arrangement, however, Scotland's EFTA membership might prove quite beneficial. For instance, it could allow Scotland to remain outside the EU's and within the UK's customs union. ${ }^{53}$ Such arrangement could absorb some of the tensions that a customs border between Scotland and the rest of Britain would create, as we will discuss in a later section. In addition, it could allow Scotland to be outside the Common Fisheries Policy and not to adopt the Euro as its currency.

\section{Reunifying a Member State}

Concerning Northern Ireland, the situation again seems to be simpler from an EU law point of view. The secession of Northern Ireland will not mean the creation of a new (Member-)State. Instead, it will trigger the territorial expansion of an EU Member State -the Republic of Ireland- to which EU law already applies in accordance with Article 52 TEU. In a way, the reunification of Ireland could follow the precedent of the German reunification where the application of the acquis was extended to East Germany without an amendment of the primary legislation, ${ }^{54}$ as agreed in a special meeting of the European Council in Dublin on 28 April 1990. 'The necessary acts of secondary law were adopted on the basis of delegation of powers to the Commission, in order to avoid that the EU legislative process was overtaken by the speed of historical events. ${ }^{56}$ The difference is that, in the case of Germany, the acquis did not apply at all in the East before the reunification, something that is very different with the situation in Northern Ireland. ${ }^{57}$

\footnotetext{
51 Available at http://www.telegraph.co.uk/news/2017/03/19/alex-salmond-independent-scotland-joinefta-get-single-market/ (last visited 28 August 2017).

52 The EFTA Member States are Iceland, Liechtenstein, Norway and Switzerland.

${ }^{53}$ Art 56(3) of the EFTA Convention requires a new member of EFTA to 'apply to become a party to the free trade agreements between the Member States on the one hand and third states, unions of states or international organisations on the other.' Despite the language, it seems that the legal framework of EFTA is flexible enough to allow Scotland not to 'sign up to those trade agreements with third countries that would be incompatible with its customs relationship with rUK.' T Lock, 'Scotland's Place in Europe After Brexit: Between a Rock and a Hard Place? A Legal Scoping Exercise’ (2017) 2 European Papers 183, 190.

${ }^{54}$ For an analysis of the Community law implications of the German reunification see generally $\mathrm{C}$ Tomuschat, 'A United Germany within the European Community' (1990) 27 Common Market Law Review 415; CWA Timmermans, 'German Unification and Community Law' (1990) 27 Common Market Law Review 437.

${ }_{55}$ The text is available at http://aei.pitt.edu/1397/1/Dublin_april_1990.pdf (last visited 28 August 2017).

${ }^{56}$ D Schiek, "'Hard Brexit"-How to address the new conundrum for the Island of Ireland?' available at https://blogs.qub.ac.uk/tensionatthefringes/files/2017/02/Schiek-Brexit-and-the-UK-Irelandrelationship-CETLS-TREUP-occasional-paper-2-20171.pdf (last visited 28 August 2017).

${ }^{57}$ The relationship of the DDR with the then Community was clarified in the judgment of the Court of Justice in Case 14/74, EU:C:1974:92. In that decision, the Court held that the relevant rules
} 
However, former Taoiseach Enda Kenny has asked recently for a special provision in any Brexit deal to allow Northern Ireland to rejoin the EU should it be united with the Republic. ${ }^{58} \mathrm{He}$ did so, notwithstanding the fact that a special deal for Northern Ireland is the declared goal of the UK government. ${ }^{59}$ So, the question is what would such a provision look like.

There are few EU law provisions that regulate the (re)unification of (Member)States. The closest example is Article 4 of Protocol No 10 on Cyprus of the Act of Accession 2003. Protocol No 10 provides the terms for the application of EU law in Cyprus given that the island had not been unified at the moment it joined the EU. In particular, it provides for the suspension of the application of the acquis in northern Cyprus, a suspension which shall be lifted in the event of a solution. ${ }^{60}$ If such solution occurs in the future, Article 4 provides for a simplified procedure that enables the Union to accommodate the terms of the reunification plan. In particular, Article 4 allows the EU, by a unanimous Council Decision at a future date and in the event of reunification, to alter the terms of Cyprus' EU accession that are contained in the Act of Accession 2003. In other words, it allows the Council to amend primary law (ie Act of Accession 2003) with a unanimous decision.

However, the Treaties foresee special procedures for their amendment in some cases. The best example, for the purposes of the present article is the Council decision on the basis of Article 2(2) of the 1994 Accession Treaty, which adjusted the instruments of accession after Norway's failure to ratify. ${ }^{61}$ Several Articles of this Accession Treaty and of the Act of Accession were amended by a Council decision while other provisions were declared to have lapsed. Thus, in that case, the Council, itself, amended primary law in a simplified procedure without any ratification of the Member States.

To the extent that the 'Brexit' Agreement will be considered as part of primary law, a similar provision regulating the reunification of Ireland could be included and could assist the smooth transitioning of Northern Ireland back to the EU. Of course, the question of the reunification of Ireland -as many other questions related to Brexitis first and foremost political. It is important to point out, however, that EU law is flexible enough to accommodate such political developments.

\section{REMAINING IN THE UK, REMAINING IN THE SINGLE MARKET}

\footnotetext{
exonerating West Germany from applying the rules of EEC law to German Internal Trade 'does not have the result of making the German Democratic Republic part of the Community, but only that a special system applies to it as a territory which is not part of the Community'.

${ }^{58}$ Available at https://www.theguardian.com/politics/2017/feb/23/irish-leader-enda-kenny-calls-forunited-ireland-provision-in-brexit-deal (last visited 28 August 2017).

${ }^{59}$ The European Council agreed the following statement in the minutes to the agreement on the Brexit negotiating guidelines on 29 April 2017: 'The European Council acknowledges that the Good Friday Agreement expressly provides for an agreed mechanism whereby a united Ireland may be brought about through peaceful and democratic means; and, in this regard, the European Council acknowledges that, in accordance with international law, the entire territory of such a united Ireland would thus be part of the European Union.' European Council, Minutes of Special meeting of the European Council (Art.50) held on 29 April 2017 (23 June 2017); available at http://data.consilium.europa.eu/doc/document/xT-20010-2017-INIT/en/pdf (last visited 28 August 2017).

${ }^{60}$ Art 1 of Protocol No 10 on Cyprus of the Act of Accession 2003 [2003] OJ L 236/955.

${ }^{61}$ Council Decision 95/1/EC, Euratom, ECSC of the Council of the European Union of 1 January 1995 adjusting the instruments concerning the accession of new Member States to the European Union [1995] OJ L $1 / 1$.
} 
From an EU law point of view, for Scotland and Northern Ireland to remain in the EU and/or the single market as a result of their secession from the UK is relatively 'straightforward'. There is a debate concerning the appropriate procedure that has to be followed in the case of Scotland, but there is not much need for legal ingenuity. Such ingenuity would be desperately needed if Scotland and Northern Ireland decide to remain in the EU and/or the single market without seceding from the UK.

In order to explore how this might be possible, I will, first, briefly review those cases where different parts of a Member State may have different relationships with the EU. Arguably, those different parts are small territorial exceptions because of certain historical and political circumstances or even insularity. In addition, in all the cases, the metropolitan State fully participates in the political and constitutional life of the EU, something that would not apply to the case of the UK in the future. More importantly, in all those cases the relevant regions have opted out from areas of EU law while Scotland and Northern Ireland would opt in the Union legal order in case they want to remain in both the UK and the EU. Notwithstanding, it is important to revisit them in order to understand the legal mechanisms that allow territorial differentiation in EU law and appreciate the remarkable flexibility of the Union legal order to accommodate such differentiation. In a sense, those examples might provide some inspiration for the legal arrangements that have to be found if England and Wales leave the EU while Scotland and Northern Ireland remain in the EU without seceding from the UK. They can also serve as a reminder of how difficult (but not unmanageable) such a task may prove to be.

\section{A. Territorial Differentiation}

Territorial/geographical exceptions to the application of EU law are more common than conventional wisdom might suggest. ${ }^{62}$ For instance, the UK has opted out from the main part of Schengen and has not adopted the euro. But those are derogations that apply to the whole territory of the Member State. For the purposes of the current article, we should focus on those cases where different parts of a Member State may have different relationships with the EU. Indeed, in many Member States, there are special territories which for either historical, geographical or political reasons have differing relationships with their national Governments - and consequently also the European Union - than the rest of the Member State's territory. Many of these special territories do not participate in all or any EU policy areas and programs. Some have no official relationship with the EU, while others participate in EU programs in line with the provisions of European Union directives, regulations or protocols attached to the European Union treaties and especially the relevant Treaties of Accession. ${ }^{63}$

\footnotetext{
${ }^{62}$ For a comparative approach of the suspension of the acquis in northern Cyprus see generally $\mathrm{N}$ Skoutaris, 'The Status of Northern Cyprus under EU Law. A Comparative Approach to the Territorial Suspension of the Acquis' in D Kochenov (ed), On Bits of Europe Everywhere. Overseas Possessions of the EU Member States in the Legal-Political Context of European Law (Kluwer Law International, 2011).

${ }^{63}$ For a comprehensive analysis of the application of Union law to Overseas Countries and Territories (OCTs) and to Outermost Regions see generally D Kochenov (ed), On Bits of Europe Everywhere. Overseas Possessions of the EU Member States in the Legal-Political Context of European Law (Kluwer Law International, 2013); D Kochenov, 'Procedural Issues in the Application of European Law in the Overseas Possessions of European Union Member States' (2008) 17 Michigan State of International Law 195; D Kochenov 'The Impact of European Citizenship on the Association of the Overseas Countries and Territories within the European Community' (2009) 36 Legal Issues of Economic Integration 239; F Murray, EU and Member State Territories, The Special Relationship under Community Law (Sweet \& Maxwell, 2004); J Ziller, 'Flexibility in the Geographical Scope of
} 
First of all, there are eight regions of EU Member States called the Outermost regions, ${ }^{64}$ where the acquis, generally speaking, applies by virtue of Article 355(1) TFEU. However, the Council, 'taking account of the structural social and economic situation' of these regions and 'their remoteness, insularity, small size, difficult topography and climate, economic dependence on a few products, the permanence and combination of which severely restrain their development', has adopted 'specific measures aimed, in particular, at laying down the conditions of application' of the Treaties to those regions, including common policies. ${ }^{65}$ So, in practical terms, while EU law applies fully there, there are derogations to its application. ${ }^{66}$

Apart from the Outermost regions, there are some other territories that enjoy ad hoc arrangements in their relationship with the EU. In most of those cases, their status is governed by protocols attached to their respective countries' accession treaties. The rest owe their status to European Union legislative provisions which exclude the territories from the application of the legislation concerned.

According to Article 355(3) TFEU, the Treaty applies to 'the European territories for whose external relations a Member State is responsible'. In practice, Gibraltar is the only territory covered by this clause. Gibraltar, a British overseas territory, is part of the EU, having joined the European Economic Community with the UK in 1973. By virtue of Article 28 of the UK Accession Treaty, Gibraltar is outside the Customs Union and VAT Area and is excluded from the Common Agricultural Policy.

Pursuant to Article 355(4) TFEU, the Treaties also apply to the Åland Islands, a group of Swedish-speaking Finnish islands off the Swedish coast, in accordance with Protocol No 2 of the Finnish Act of Accession 1994. There, derogations to the free movement of people and services, the right of establishment and the purchase or holding of real estate are provided. ${ }^{67}$

The EU Treaties apply to the Channel Islands and the Isle of Man as well but to the extent necessary to ensure the implementation of the 'arrangements for those

EU Law: Diversity and Differentiation in the Application of Substantive Law on Member States' Territories' in G de Búrca and J Scott (eds), Constitutional Change in the EU: From Uniformity to Flexibility (Hart Publishing, 2000) 113; J Ziller, 'Les collectivités des outre-mer de 1'Union européenne'in JY Faberon (ed), L' Outre-mer Français: La nouvelle donne institutionelle (Documentation française, 2004); J Ziller, 'L' Union européene et l'outre-mer' (2005) 113 Pouvoirs 145; J Ziller, 'The European Union and the Territorial Scope of European Territories' (2007) 38 Victoria University Wellington Law Review 51.

${ }^{64}$ The Outermost regions are French Guadeloupe, French Guiana, Martinique and Réunion, SaintBarthélemy, Saint-Martin, the Spanish Canary Islands and the Portuguese Azores and Madeira. Mayotte became an outermost region of the European Union on 1 January 2014, following a 2009 referendum with an overwhelming result in favour of the department status.

${ }^{65}$ Article 349 TFEU. In June 2001 the Council adopted two sets of Regulations based on the priorities identified in the Commission Report on the measures to implement Art 299(2) TEC: the Outermost regions of the European Union, COM(2000) 147, 14 March 2000. The first set of Regulations (Council Regulations 1447/2001, 1448/2001, 1449/2001, 1450/2001, 1451/2001, [2001] OJ L198/1) aimed to take fuller account of the specific nature of the Outermost regions, under the Structural Funds, as defined in Article 349 TFEU, while the second set (Council Regulations 1452/2001, 1453/2001, 1454/2001, [2001] OJ L198/11) aimed to amend the CAP in order to take greater account of the specific local conditions of the region.

${ }^{66}$ For a comprehensive analysis of the application of the acquis in the Outermost Regions see generally Kochenov, 'Substantive and Procedural Issues in the Application of European Law in the Overseas Possessions' (above n 63) 227-244 and 268-286.

${ }^{67}$ Act concerning the condition of accession of the Kingdom of Norway, the Republic of Austria, the Republic of Finland and the Kingdom of Sweden and the adjustments to the Treaties on which the European Union is founded [1994] OJ C 241/21. 
islands set out' in Protocol No 3 of the Act of Accession 1972. ${ }^{68}$ This effectively means that they are part of the Union only for the purposes of customs and the free movement of goods and in relation to some aspects of the Common Agricultural Policy.

In contrast to the formerly mentioned areas, the Treaties do not apply in the Faroe Islands pursuant to Article 355(5)(a). They have, however, the status of a third country enjoying preferential treatment with respect to the Union. That status is regulated by two basic agreements, one concerning fisheries ${ }^{69}$ and the other trade. ${ }^{70}$

Another category of differentiated integration concerns the Overseas Territories. Each one of them has a special relationship with one of the Member States of the Union. ${ }^{71}$ Part Four of the TFEU Treaty governs their relationship with the EU. They were invited to form association agreements with the $\mathrm{EU}^{72}$ and may opt-in to EU provisions on the freedom of movement for workers ${ }^{73}$ and freedom of establishment. ${ }^{74}$ They are not subject to the EU's common external tariff ${ }^{75}$ but may claim customs duties on goods imported from the EU on a non-discriminatory basis. ${ }^{76}$ They are not part of the EU and EU law applies to them only insofar as is necessary to implement the association agreements. ${ }^{77}$ Concerning the Union citizenship status of the inhabitants of the OCTs, we could argue that, although the OCTs fall de jure outside the territorial scope of the Treaties, their inhabitants are considered Union citizens. $^{78}$

Finally, for the sake of completeness, we could also refer to the special status of the German enclave town of Büsingen am Hochrhein and the Italian enclaves of Campione d'Italia and Livigno which are all fully surrounded by Switzerland and the Spanish enclaves of Ceuta and Melilla on the Moroccan coast. All those enclaves and the German island of Heligoland, despite their different locations, are excluded from the Customs Union $^{79}$ and the VAT area. ${ }^{80}$

\footnotetext{
${ }^{68}$ Article 355(6)(c) TFEU.

${ }^{69}$ Council Regulation (EEC) No 2211/80 of 27 June 1980 on the conclusion of the Agreement on fisheries between the European Economic Community and the Government of Denmark and the Home Government of the Faroe Islands [1980] OJ L226/1.

${ }^{70}$ Council Decision 97/126/EC of 6 December 1996 concerning the conclusion of an agreement between the European Community, on the one part, and the Government of Denmark and the Home Government of the Faroe Islands, on the other [1997] OJ L53/1.

${ }^{71}$ Twelve with the UK: Anguilla, Cayman Islands, Falkland Islands, South Georgia and the South Sandwich Islands, Montserrat, Pitcairn, Saint Helena and the Dependencies, British Antarctic Territory, British Indian Ocean Territory, Turks and Caicos Islands, British Virgin Islands and Bermuda (Bermuda, although formally an OCT listed in Annex II, does not benefit from the EU-OCT Association); Five with France: New Caledonia and Dependencies, French Polynesia, French Southern and Antarctic Territories, Wallis and Futuna Islands (known collectively as 'Territoires d'outre mer') and Saint Pierre and Miquelon; Two with the Netherlands: Aruba and the Netherlands Antilles (Bonaire, Curaçao Saba, Sint Eustatius and Sint Maarten); and one with Denmark: Greenland.

${ }^{72}$ Article 198 TFEU.

73 Article 202 TFEU.

${ }^{74}$ Article 199(5) TFEU.

${ }^{75}$ Article 200(1) TFEU.

${ }_{77}^{76}$ Article 200(3) and (5) TFEU.

${ }^{77}$ Article 355(2) TFEU.

${ }^{78}$ See Eman and Sevinger v College van Burgemeester en Wethouders van Den Haag, C-300/04, EU:C:2006:545.

${ }^{79}$ Article 3 of Council Regulation (EEC) No 2913/92 of 12 October 1992 establishing the Community Customs Code [1992] OJ L302/1.

${ }^{80}$ Article 6 of Council Directive 2006/112/EC of 28 November 2006 on the common system of value added tax, [2006] OJ L 347/1.
} 
This brief study shows, in the most emphatic way, that the application of the acquis has been influenced on many occasions by certain historical, political or even geographical conditions. The width and breadth of the subject matter of those territorial exceptions cannot be overstated. Having said that, only in the case of Greenland was the territorial differentiation a result of the decision of the people to withdraw from the EU in a referendum. More importantly, in all those cases, the metropolitan State takes full part in the political and constitutional life of the EU. Notwithstanding, it is important to note for the purposes of our paper that the EU legal order allows for the differentiated application of the acquis within different parts of the same Member State.

\section{B. The Quest for a Differentiated Brexit: From 'Reverse Greenland' and Cyprus to Reverse Svalbard}

\section{Remaining in the EU and/or the single market}

As I mentioned before, the only historical precedent of a territory that voted to withdraw from the EU is Greenland. Greenland is an autonomous territory under the Danish sovereignty. In 1982, Greenlanders voted against being subject to the EEC Treaty. After three years of negotiations, the Member States concluded the Greenland Treaty on its new status under EU law. According to this Treaty, Greenland became an associated territory under Article 204 TFEU. As a result, Part Four of TFEU on the Association of the Overseas Countries and Territories applies to Greenland. Notwithstanding, Greenlanders are still Union citizens. ${ }^{81}$

The fact that Greenland is the only historical precedent of a partial territorial withdrawal from the EU has led a number of experts to discuss whether a 'Reverse Greenland' model could be used if Scotland and Northern Ireland decide to remain both in the EU without seceding from the UK. ${ }^{82}$ According to this model, the Treaties would be amended to the extent that Union law would not apply to England and Wales but would fully apply to the other two constituent nations.

The Scottish Government, however, has accepted that the 'Reverse Greenland' model is 'unlikely to attract the support of the UK Government as both would require the UK formally to remain a Member State of the EU, something that the UK Government has indicated it will not do. ${ }^{83}$ This is why, they have proposed as an alternative that Scotland should remain in the EEA and thus in the single market. A similar proposal has been put forward by a number of academics with regard to Northern Ireland. ${ }^{84}$

Both proposals envisage two pathways for those regions to achieve EEA membership. The first option entails a UK-sponsored membership. The UK will opt for membership to the EEA but there will be a territorial exemption for England and Wales. The EEA acquis will fully apply only in Scotland and/or in Northern Ireland. The precedent for that can be also found in the Arctic circle. Norway has secured a

\footnotetext{
${ }^{81}$ Treaty Amending, With Regard to Greenland, the Treaties Establishing the European Communities, [1985] OJ L29/1; F Weiss, 'Greenland's Withdrawal from the European Communities', (1985) 10 European Law Review 173.

${ }^{82}$ See for instance T Lock, 'A European Future for Scotland?', available at verfassungsblog.de/aeuropean-future-for-scotland/; https:/www.opendemocracy.net/uk/adam-ramsay/reverse-greenlandletting-scotland-stay (last visited 28 August 2017).

${ }^{83}$ Above n 6, para 118.

${ }^{84}$ B Doherty et al., 'Northern Ireland and Brexit: The European Economic Area Option' EPC Paper, available at http://epc.eu/documents/uploads/pub_7576_northernirelandandbrexit.pdf (last visited 28 August 2017).
} 
territorial exemption for the insular islands of the archipelago of Svalbard that are not part of EEA. ${ }^{85}$ Alternatively, there should be an amendment of the EFTA Convention and the EEA Agreement that would allow the membership of sub-state entities. To this effect, it should be pointed out that although it is not an independent State, the Faroe Islands is currently exploring the possibility of joining EFTA. ${ }^{86}$

Theoretically speaking, all the aforementioned options are legally possible. There are certain legal and practical issues that would have to be dealt with, not least because - unlike Greenland, Faroe Islands and Denmark and Norway and Svalbard Scotland and England share a territorial border. Were the UK to leave the single market and customs union as Theresa May announced in her Lancaster House speech, ${ }^{87}$ so long as Scotland remained in a customs union with the rest of the UK, there would be no need for a customs frontier between Scotland and England. However, if free movement of people did not apply to England and Wales but did apply to Scotland through the EEA, there is a question to be posed about how this may influence people crossing between the two sides of the internal border given the existence of the Common Travel Area (CTA). ${ }^{88}$

This is exactly why in the next section we would be also referring to how the EU has dealt with the case of Cyprus. Cyprus is the only Member State where the acquis does not apply to a significant part of its territory and there is a territorial border between the part where it applies and where it does not. Of course the historical and political conditions that led to the suspension of the acquis ${ }^{89}$ in Cyprus does not bear any resemblance to the post-Brexit political situation in the UK. However, the legal arrangements that were used in order to accommodate the Cyprus problem could offer some much needed inspiration if Scotland and Northern Ireland were to decide to remain in the EU and/or the single market without seceding from the UK.

What is important to note for the purposes of the present paper is that Article 2 of Protocol No 10 has allowed for the adoption of the Green Line Regulation. ${ }^{90}$ This is an interesting piece of legislation because it regulates the free crossing of people and goods between an area of a Member State where the free movement acquis applies and is within the customs union and one where the free movement acquis does not apply and is outside the customs union. In that sense, we will refer to it as a useful legal tool that could provide for some inspiration if Scotland and Northern Ireland decide to remain in the EU and/or the single market. Interestingly enough, the UK Government explicitly referred to the Green Line Regulation as one of the examples

\footnotetext{
${ }^{85}$ Protocol 40 on Svalbard of the Agreement on the European Economic Area [1994] OJ L1/208.

${ }^{86}$ For an analysis of the EU status of the Faroe Islands, see J Hartmann, 'The Faroe Islands: possible lessons for Scotland in a new post-Brexit devolution settlement' available at https://papers.ssrn.com/sol3/papers.cfm?abstract_id=2909543 (last visited 28 August 2017).

${ }_{87}$ Available at http://www.telegraph.co.uk/news/2017/01/17/theresa-mays-brexit-speech-full/ (last visited 28 August 2017).

${ }^{88}$ The Common Travel Area (CTA) is a special travel zone between the Republic of Ireland and the UK, Isle of Man and Channel Islands. It dates back to the establishment of the Irish Free State in 1922. Nationals of CTA countries can travel freely within the CTA without being subject to passport controls.

${ }^{89}$ Article 1 of Protocol No 10 (above n 60).

${ }^{90}$ Council Regulation (EC) No 866/2004 of 29 April 2004 on a regime under Article 2 of Protocol 10 to the Act of Accession [2004] OJ L 206/51. For a comprehensive analysis of the Green Line Regulation regime see N Skoutaris, 'The application of the acquis communautaire in the areas not under the effective control of the Republic of Cyprus: The Green Line Regulation', 45 Common Market Law Review (2008) 727.
} 
'of where the EU has set aside the normal regulations and codes set out in EU law in order to recognise the circumstances of certain border areas. ${ }^{91}$

\section{The application of the fundamental freedoms}

Article 21 TFEU, provides that every EU citizen has the 'right to move and reside freely within the territory of the Member States'. One of the declared goals of Brexit is to terminate the application of free movement of people in the UK. If Scotland and/or Northern Ireland, however, remain in the single market the relevant Treaty provisions will be applying to part of the territory of the State in the same way that they apply only South of the Green Line but not in northern Cyprus.

This means that there is a possibility of a border between the areas where the free movement acquis applies and the ones where it does not. In order to deal with this situation in Cyprus, where free movement of people is suspended only in part of its territory, the Republic of Cyprus carries out checks on all persons crossing the Green Line with the aim of combating illegal immigration of third-country nationals and to detect and prevent any threat to public security and public policy. ${ }^{92}$ All persons crossing the line should undergo at least one such check in order to establish their identity. ${ }^{93}$

If a similar measure were to be applied in the territorial border between England and Scotland or the maritime border between Northern Ireland and the Rest of the UK, it would be the Scottish/Northern Irish authorities that would have to police this 'EU border'. It is interesting to note that the Cypriot authorities carry out checks on all persons crossing the borders including their own citizens and other EU citizens, not least because Cyprus is also not part of the Schengen Area. By analogy, this would mean that the Scottish/Northern Irish authorities would be faced with the tantamount task of policing a border that tens of millions cross every year.

Of course, such hard border can be avoided if UK remains in the single market. However, following Theresa May's Lancaster House speech such prospect seems unrealistic. A more realistic option to avoid a hard border would entail that immigration checks would be conducted in places other than borders. For instance, Ruparel has suggested that 'the enforcement of ensuring people do not over-stay' can take place "via other mechanisms such as regulating access to social security and the job market." 94

Undoubtedly, all the aforementioned arrangements sound arduous and cumbersome. However, it should be noted that unless a similar arrangement to the one described in this section, is achieved with regard to Northern Ireland, the same problems will occur mutatis mutandis in the Irish border post-Brexit. ${ }^{95}$ The difference is that a hard Irish border would pose a significant threat to the stability of the fragile peace process.

\footnotetext{
${ }^{91}$ Above n 17, para 42. For an analysis see N Skoutaris, 'Footnotes in Ireland' available at http://www.skoutaris.eu/blog/2017/8/18/footnotes-in-ireland (last visited 28 August 2017).

${ }_{92}$ Article 2(1) of the Green Line Regulation

${ }^{93}$ Article 2(2) of the Green Line Regulation.

${ }^{94} \mathrm{~T}$ McGuiness and M Gower, 'The Common Travel Area and the special status of Irish nationals in UK law' House of Commons Briefing Paper No 7661, 18.

${ }^{95}$ The analogy between the post-Brexit situation in the Irish border and the territorial border between England and Scotland if the latter remains in the single market were also underlined by the Scottish Government. In their 2016 blueprint on Scotland's Place in Europe, they suggested that whatever instruments are used for the Northern Ireland/Republic of Ireland border should be applied mutatis mutandis between Scotland and England.
} 
Concerning the free movement of persons, the challenges that would arise if Scotland and/or Northern Ireland remain in the single market are identical whether they would be members of the EU or the EEA. However, with regard to the free movement of goods, the choice between the two is significant. The reason being that if an area is not within the EU (including the ones that are part of the EEA), it is outside the EU's customs union. So, it has a customs border with the European Union. At the same time, this means that it can negotiate its own free trade and customs unions.

Starting with the scenario according to which Scotland and/or Northern Ireland remain within the EU's customs union. This means that there would be a customs border between those two regions and the rest of the UK given that the current administration has clarified that their goal is that the UK would be outside the EU's customs union. Again, it is interesting to look at how the EU managed to regulate its trade relations with northern Cyprus which is outside the customs union and where free movement of goods does not apply. In agreement with the Republic of Cyprus, the EU authorised a Turkish Cypriot NGO, the Turkish Cypriot Chamber of Commerce, ${ }^{96}$ to issue accompanying documents so that goods originating in northern Cyprus may cross the line and be circulated in South Cyprus and the Union market. More importantly, those goods are deemed as originating in Cyprus/EU and thus they are not subject to customs duties or charges having equivalent effect when they are introduced in the Government Controlled Areas. ${ }^{97}$ Similar agencies could be authorised in England and Wales in order their traders not to face the Union common external tariff even when they 'export' to Scotland and Northern Ireland. Alternatively, there could be free crossing of goods with tighter checks at certain focal points such as ports and airports.

Of course, if the UK signs a Free Trade Agreement with the EU, goods that would be wholly obtained or have undergone their last, substantial, economically justified processing or working, in an undertaking equipped for that purpose, in England and Wales ${ }^{98}$ would not be subject to customs duties or charges having equivalent effect. ${ }^{99}$ All the other goods, however, would face Union common external tariff.

This is perhaps why the Scottish Government ${ }^{100}$ and the aforementioned group of academics ${ }^{101}$ have prioritised Scotland and Northern Ireland remaining in the EEA. That would allow goods originating from those regions to move freely in the EU, while remaining outside of the EU's customs union. In that case, the border between Ireland and Northern Ireland would resemble the Sweden/Norway customs border where the use of technology has minimised the disruption arising from a customs border between a State that is within the EU's customs union and one that is not.

\section{Constitutional Reconfiguration}

\footnotetext{
${ }^{96}$ Article 4(5) of the Green Line Regulation; Commission Decision 2004/604/EC of 7 July 2004 on the authorisation of the Turkish Cypriot Chamber of Commerce according to Article 4(5) of Council Regulation (EC) No 866/2004, [2004] OJ L 272/12.

${ }^{97}$ Article 4(2) of the Green Line Regulation.

${ }^{98}$ Council Regulation (EEC) No 2913/92 establishing the Union Customs Code [1992] OJ L 302/1.

${ }^{99}$ A similar arrangement applies to goods originating in northern Cyprus, Article 4(2) of the Green Line Regulation.

${ }^{100}$ See above n 6.

${ }^{101}$ See above n 84 .
} 
In the previous section, we managed to appreciate some of the issues that would have to be addressed if Scotland and Northern Ireland are to remain in the EU and/or the single market without seceding from the UK. All those issues relate one way or another to the differentiated application of the fundamental freedoms. However, in such a scenario, there also needs to be a fundamental constitutional amendment of the relevant Devolution Acts, not least in order for the devolved administrations to possess the relevant competences to take decisions at the EU/EEA level. In fact, the Scottish Government has argued that Scotland would have to acquire competences in a number of areas, such as international relations like the Belgian sub-state entities and immigration like Quebec. ${ }^{102}$

The flexible nature of the idiosyncratic UK constitution suggests that the hurdle will not be insurmountable from a legal point of view. In fact, one could argue that the EU (Withdrawal) Bill offers a chance to enhance and strengthen the competences of the devolved governments instead of limiting their subconstitutional $^{103}$ space as the Scottish Government argues that it does in its current form. ${ }^{104}$ Having said that, such an amendment to the devolution arrangement would mark the complete transformation of the UK state to one of the most decentralised in the world. The government of the United Kingdom would have to at least share its competences with the devolved administrations, even in the area of external relations and defence, to the extent that Scotland and Northern Ireland might want to participate in the Common Foreign and Security Policy and the Common Security and Defence Policy. Moreover, their ministers would need to be able to sign international agreements, such as multilateral conventions that are concluded as mixed agreements. In that sense, Scotland and Northern Ireland would be arguably the regions with the highest legislative autonomy in the world, making it hard to see the difference between their status and independence. ${ }^{105}$

The representation of Scotland and Northern Ireland in the EU/EEA would also have to be settled. The reason being that, if England and Wales withdraw from the EU/EEA, it would be practically impossible and politically not prudent for the UK government to represent the two constituent nations that have remained in the single market to the relevant institutions.

So, if the two regions succeed in remaining in the EU without seceding from the UK, they would 'need to speak with a single voice and ensure proper application of European Union law' as the European Council has noted. ${ }^{106}$ This reflects both the pragmatic and the legal demands of Union membership as it affects the 'interface' between the Member State and the Union. With regard to the 'single voice' requirement, we note that it is relevant for many kinds of decision-making procedures. Ways will need to be found to ensure that Scotland and Northern Ireland are represented in various EU fora, such as the European Council. ${ }^{107}$ Moreover, although

\footnotetext{
${ }^{102}$ See, for instance, above n 6, para 163.

${ }^{103}$ E Posner and T Ginsburg, 'Subconstitutionalism', John M Olin Law and Economics Working Paper No. 507, available at

http://chicagounbound.uchicago.edu/cgi/viewcontent.cgi?article=1466\&context=law_and_economics (last visited 28 August 2017).

${ }^{104}$ See M Elliott, 'A “blatant power grab”? The Scottish Government on the EU (Withdrawal) Bill', available at https://publiclawforeveryone.com/2017/08/10/a-blatant-power-grab-the-scottishgovernment-on-the-eu-withdrawal-bill/ (last visited 28 August 2017).

${ }^{105}$ I would like to thank professor Cremona for pointing this out to me.

${ }^{106}$ Council of the European Union, Seville European Council 21 and 22 June 2002, Presidency conclusions (13463/02), para 24.

${ }^{107}$ Art 15 TEU.
} 
Article 16 TEU provides that the Council consists 'of a representative of each Member State at ministerial level, who may commit the government of the Member State in question and cast its vote', it is not prescribed to which internal level of government that representative shall belong. A number of paradigms arising from EU Member States practices exist. ${ }^{108}$ So it would be for the two regions to decide which minister of which regional government would represent them each and every time. ${ }^{109}$ To this effect, it is important to note that an EU Member State is free to cast a positive or negative vote or to abstain from voting in the EU decision-making process. Thus, if the governments of the two UK constituent nations cannot adopt a common position in some EU matters, that would not be in conflict with Union law.

The conclusions of the Seville European Council also underlined that Member States need 'to... ensure proper application of European Union law'. ${ }^{110}$ This is a reference to Article 4 TFEU, according to which an EU Member State should 'take any appropriate measure, general or particular, to ensure fulfilment of the obligations arising out of the EU Treaties or resulting from the acts of the institutions of the Union'. With regard to that, firstly, note that since the 1964 Costa v ENEL judgment ${ }^{111}$ of the Court of Justice, EU law enjoys supremacy over national law, including constitutional law. ${ }^{112}$ Member States, however, are free to decide on how to integrate this principle into their national law. ${ }^{113}$ In fact, both the Scotland Act 1998 and the Northern Ireland Act 1998 already provide that the Acts of the devolved legislatures should not be incompatible with EU law. ${ }^{114}$

In addition to respecting the supremacy of EU law, the two regions would also have to establish a mechanism to ensure compliance with Union law in the case of a regional 'blocking' i.e. the inability of one of the two to comply with a certain piece of EU legislation. This is particularly important for our case because the CJEU has repeatedly held that a Member State may not plead provisions, practices or circumstances existing in its internal legal system in order to justify a failure to comply with the obligations and time limits laid down in a directive. ${ }^{115}$

\footnotetext{
${ }^{108}$ For different models of representation at the various institutions see N Skoutaris 'The Role of SubState Entities in the EU Decision-Making Processes: A Comparative Constitutional Law Approach' in E Cloots, G De Baere and S Sottiaux (eds), Federalism in the European Union (Hart Publishing, 2012) 210.

${ }^{109}$ For some suggestions of how this can happen see B O'Leary 'Detoxifying the UK's exit from the EU: a multi-national compromise is possible' available at http://blogs.lse.ac.uk/brexitvote/2016/06/27/de-toxifying-the-uks-eu-exit-process-a-multi-nationalcompromise-is-possible/ (last visited 28 August 2017).

${ }^{110}$ Seville European Council conclusions (above n 106), para 24.

${ }^{111}$ Costa v ENEL, 6/64, EU:C:1964:66.

${ }^{112}$ Internationale Handelsgesellschaft mbH v Einfuhr- und Vorratsstelle für Getreide und Futtermittel, 11/70, EU:C:1970:114; Commission v Luxembourg, C-473/93, EU:C:1996:263.

${ }^{113}$ German (Art 23 of German Basic Law) and Italy (Art 11 of the Italian Constitution) have interpreted their respective constitutional provisions, relating to the EU or international relations, as embodying the supremacy of EU law by a 'material change' of the constitution. France (Arts 54 and 55 of the French Constitution) requires a formal change of the specific constitutional provisions before ratifying a Treaty that would otherwise entail obligations that are not compatible with those provisions. Art. 29(5) of the Irish Constitution has expressly incorporated the principle of supremacy to the Constitution.

${ }^{114}$ Scotland Act 1998, section 29(2)(d); Northern Ireland Act 1998, section 24.

${ }^{115}$ Commission v Spain, C-107/96, EU:C:1997:286; Commission v Belgium, C-323/97, EU:C:1998:347.
} 


\section{CONCLUSION}

This paper explores two pathways for Scotland and Northern Ireland to remain in the EU. The reason for this intellectual exercise is that - unlike England and Wales - the other two UK constituent nations voted to remain in the EU. More importantly, their political leaderships have declared that they do not wish the regions to be taken out of the EU against their will. The first pathway entails their secession from the UK. However, we noted that, while Northern Ireland enjoys such a constitutional right, Scotland has to reach a similar arrangement such as the one that led to the organization of the 2014 independence referendum. But even if an Edinburgh Agreement II is reached, there is a question whether the relevant provision regulating Scotland's EU accession would be Article 48 or 49 TEU.

The second pathway does not entail their secession from the UK. Instead, England and Wales will withdraw from the EU while Scotland and Northern Ireland will remain. Although, the Union legal order is characterised by remarkable pragmatic flexibility, as is evident from a number of cases of territorial differentiation, there are a number of issues that have to be addressed in order for such an arrangement to be achieved. Those issues relate to the fact that such a solution would entail the existence of a customs border and border checks within the territory of the UK. In addition, a dramatic constitutional amendment to the devolution arrangement would have to take place in order for both regions to take part effectively in the political and constitutional life of the EU and the EEA.

Given the dramatic changes that such an arrangement would mark to the constitutional status quo of the UK, one has to wonder why the UK government would opt for such a solution. In fact, David Davis has pointed out that 'such arrangements could lead to the creation of new barriers to trade within our union'. ${ }^{116}$ At the same time, such special arrangement for Northern Ireland might be deemed problematic for the Unionists in Northern Ireland ${ }^{117}$ while there is always a question why the SNP would settle for something less than their secession from the United Kingdom.

For the UK government, the biggest incentive to offer such a solution to Scotland and Northern Ireland would be that it represents a tangible alternative to secession. The United Kingdom might become almost a confederation but it will still be one recognised State under international law. In other words, it could save the Union. On the other hand, the devolved administrations could also avoid the tensions and divisions that could be caused because of their secession. In particular, such a solution presents less threats to the fragile Belfast Agreement than Brexit itself or a referendum for the reunification of Ireland.

Even if neither the UK nor the devolved administrations opt for such an arrangement, it could still prove useful. It could be used transitionally until there is a renegotiation and a resettlement of the constitutional status of those two constituent nations, ensuring that they do not find themselves outside the single market even for a minute.

In any case, both the current UK and EU constitutional frameworks somehow seem to be unable to accommodate the very different aspirations of the UK constituent nations. In this sense, their significant amendment is almost unavoidable.

\footnotetext{
${ }^{116}$ Available at http://www.bbc.co.uk/news/uk-scotland-scotland-politics-39744871 (last visited 28 August 2017)

${ }^{117} \mathrm{~K}$ Hayward, 'The origins of the Irish border', available at http://ukandeu.ac.uk/explainers/theorigins-of-the-irish-border/ (last visited 28 August 2017).
} 